\title{
HUBUNGAN ANTARA UMUR DAN PARITAS DENGAN KEJADIAN ABORTUS INKOMPLIT DI RSUD RADEN MATTAHER JAMBI TAHUN 2018
}

\author{
Rini Mayasari \\ Akademi Kebidanan Budi Mulia Jambi
}

\author{
Informasi Artikel : \\ Diterima : April 2019 \\ Disetujui : Juni 2019
}

*Korespondensi Penulis :

rini_mayasari@ymail.com

\begin{abstract}
A B S T R A K
WHO memperkirakan diseluruh dunia angka abortus dengan persentase 14-15\%. Angka kematian ibu di indonesia tercatat 395/100.000 kelahiran hidup. Penyebab kematian ibu ini salah satunya adalah abortus. Angka kematian ibu akibat abortus yaitu 1,6. Tujuan penelitian ini adalah untuk mengetahui hubungan antara umur dan paritas dengan kejadian abortus inkomplit di RSUD Raden Mattaher Jambi Tahun 2018.Desain penelitian ini menggunakan metode desain penelitian kuantitatif dengan pendekatan cross sectional dimana variabel independen (umur dan paritas) dan variabel dependen (kejadian abortus inkomplit). Populasi dalam penelitian adalah seluruh ibu hamil yang mengalami abortus di RSUD Raden Mattaher Jambi dari bulan Januari sampai dengan bulan November tahun 2018 berjumlah 75 orang dengan dengan sampel penelitian sebanyak 75 orang dengan teknik sampel adalah total populasi, pengumpulan data menggunkan data sekunder. Analisa data yang digunakan adalah analisa univariat menggunakan distribusi frekuensi dan analisa bivariat menggunakan uji Chi-square melalui sistem komputerisasi.Berdasarkan hasil analisa bivariat dengan menggunkan uji statistik Chi-square didapatkan $p$ value pada variabel umur $(0,000)$ dan paritas $(0,000)$ berarti lebih kecil dari $\alpha=0,05$. Kesimpulan dari penelitian ini adalah bahwa ada hubungan yang bermakna antara umur dan paritas dengan kejadian abortus inkomplit di RSUD Raden Mattaher Jambi Tahun 2018.
\end{abstract}

Kata Kunci : Kejadian abortus Inkomplit, umur dan paritas

\section{ABSTRACT}

WHO estimates worldwide abortion rates with a percentage of 14-15\%. There are 395 of the mother mortality rate from 100.000 of life birth. One of the cause of mother is abortion. The number of the deaths 1,6\%. The objective of this reseacrh is to know the relationship between age and parity with the incomplete abortion in Regional Public Hospital Raden Mattaher Jambi in 2018. The design of this research uses quantitative research design method with cross sectional approach. The variables are independent ( age and parity) and dependent (incomplete abortion). The population in this research is all of the abortion pregnant women in Regional Public Hospital Raden Mattaher Jambi from January to November 2018 are 75 people with the research samples are 74 people with sample technique called total population. The colleting data is used secondary data. Data analysis is used univariate analysis used frequency distribution and bivariate analysis used uji Chi-square through computerization system. Based on the bivariate analysis with Chi-square concluded $p$ value to age variable $(0,001)$ and parity $(0,000)$ means it is smaller than $\alpha=0,05$. The conclusion of this research is to show that there is the meaningful relationship between age and parity and incomplete abortion in Regional Public Hospital Raden Mattaher in 2018.

Keywords: The Incomplete Abortion, The Age, and The Parity 


\section{PENDAHULUAN}

Abortus merupakan ancaman atau pengeluaran hasil konsepsi sebelum janin dapat hidup diluar kandungan. Sebagai batasan ialah kehamilan kurang dari 500 gram (Wiknjosastro, 2010).

Menurut World Health Organization (WHO) tahun 2014 bahwa 99\% kematian ibu hamil dan bersalin yang terjadi negara-negara berkembang, salah satu penyebab masalah kematian ibu tersebut disebabkan karena perdarahan, infeksi serta faktor lain yaitu abortus dimana persentasinya cukup tinggi yaitu 14-15\% angka kejadian (Kemenkes, 2015).

Angka kematian ibu di Indonesia masih tinggi dibandingkan dengan negara negara di ASEAN. Berdasarkan data Survey Demografi dan Kesehatan Indonesia (SDKI) tahun 2012, Angka Kematian Ibu (AKI) di indonesia sebesar 395 per 100.000 kelahiran hidup. Di Indonesia ada lima penyebab kematian terbesar ibu yaitu pedarahan $(30,1 \%)$, hipertensi $(26,9 \%)$, infeksi $(5,5 \%)$, partus lama $(1,8 \%)$, abortus $(1,6 \%)$, (5,5\%), dan lain-lain (34,5\%) (Depkes RI, 2015)

Target yang ditentukan oleh Sustainable Development Goals (SDGs) dalam 1,5 dekade ke depan mengenai kematian ibu adalah penurunan AKI sampai 70 per 100.000 kelahiran hidup, SDGs ini dirancang untuk melanjutkan tujuan utama MDGs yang belum tercapai, yaitu permasalahan kesehatan ibu dan anak.

Berdasarkan data kementerian kesehatan penilaian terhadap kejadian abortus pada ibu hamil di Jambi tahun 2015 yaitu dengan persentasi $51,63 \%$. Sedangkan angka kematian ibu di Jambi pada tahun 2015 berjumlah 165 orang, artinya angka kejadian abortus di Jambi masih tinggi (Kemenkes, 2015).

Jumlah kematian ibu tahun 2010 di Kota Jambi sebanyak 131 orang, pada tahun 2011 sebanyak 112 orang, pada tahun 2012 sebanyak 110 orang, pada tahun 2013 mencapai 82 orang, pada tahun 2014 mencapai 75 kasus. Berdasarkan laporan pada tahun 2015 sebanyak 55 orang dari 100.000 kelahiran hidup (Profil Pelayanan Kesehatan Dasar, 2015). Penyebabnya yaitu perdarahan $(41,7 \%)$ diikuti oleh emboli paru, suspek syok kardiogenik, eklampsia, suspek TB, hipertensi dalam kehamilan dan selebihnya disebabkan faktor lainnya termasuk abortus (Dinkes Jambi, 2015).

Ada 3 penyebab klasik kematian ibu yaitu perdarahan, keracunan kehamilan dan infeksi. Sebenarnya ada penyebab ke 4 yaitu abortus, 15$50 \%$ kematian ibu disebakan abortus, komplikasi abortus berupa perdarahan atau infeksi dapat menyebabkan kematian. Itulah sebabnya mengapa kematian ibu yang disebakan abortus sering tidak muncul dalam laporan kematian, tapi dilaporkan sebagai perdarahan atau sepsis (Azhari, 2011).

Abortus merupakan penghentian kehamilan sebelum 20 minggu kehamilan lengkap. Istilah ini digunakan untuk janin hidup maupun janin mati dengan berat $\leq 500$ gram. Namun, janin tidak perlu diidentifikasi jika terdapat produk konsepsi lainnya (misalnya plasenta atau selaput ketuban). Abortus merupakan hasil yang tidak dikehendaki pada $15 \%-40 \%$ dari semua kehamilan yang diketahui. Semakin muda kehamilan, semakin mungkin terjadi abortus. Sekitar $75 \%$ abortus terjadi sebelum umur 16 minggu, dan kira-kira 60\% terjadi sebelum 12 minggu (Pernoll, 2010).

Faktor yang mempengaruhi abortus inkomplit seperti faktor janin (kelainan telur, embrio dengan kelainan local dan abnormalitas pembentukan plasenta), faktor maternal (paritas, jarak kehamilan, infeksi, virus, penyakit vascular, kelainan endokrin,faktor imunologis, trauma) dan faktor eksternal (radiasi, obatobatan dan bahan-bahan kimia lainnya) (Sastrawinata,2015).

Risiko abortus spontan semakin meningkat dengan bertambahnya paritas dan usia ibu. Pada ibu usia dibawah 20 tahun risiko terjadinya abortus kurang dari $2 \%$. Risiko meningkat $10 \%$ pada usia ibu lebih dari 35 tahun dan mencapai 50\% pada usia lebih dari 45 tahun. Peningkatan risiko abortus ini diduga berhubungan dengan abnormalitas kromosom pada wanita usia lanjut (Cunningham, 2012).

Wanita yang hamil pada usia kurang 20 tahun retan mengalami abortus. Hal itu disebabkan karena belum matangnya alat reproduksi untuk hamil sehingga dapat merugikan kesehatan ibu maupun pertumbuhan dan perkembangan janin. Sedangkan abortus yang terjadi pada usia 35 tahun disebabkan 
karena berkurangnya fungsi alat reproduksi, kelainan kromosom (Donny, 2014).

Jumlah Paritas yang tinggi juga mempengaruhi angka kejadian abortus. Risiko terjadinya abortus meningkat seiring dengan bertambahnya paritas ibu lebih dari 3 kali mempunyai angka kematian maternal lebih tinggi. Semakin tinggi paritas maka akan semakin beresiko kehamilan dan persalinan, karena pada wanita yang sering hamil ataupun melahirkan akan mengalami kekendoran pada dinding rahim (Donny, 2014).

Adanya berbagai macam abortus tergantung penyebabnya, salah satunya adalah abortus inkompletus. Abortus inkompletus merupakan pengeluaran sebagian hasil konsepsi pada kehamilan senelum 20 minggu dengan maish ada yang tertinggal dalam uterus. Pada pemeriksaan vaginal, kanalis servikalis terbuka dan jaringan dapat diraba dalam kavum uteri (Wiknjosastro, 2010).

Sebagian abortus dapat dicegah dengan mengobati defisiensi atau gangguan pada ibu sebelum atau selama hamil (misal diabetes melitus, hipertensi) penutupan serviks yang inkompeten akan mencegah abortus tertentu (Prawirohardjo, 2010).

Studi pendahuluan yang dilakukan oleh peneliti di Rumah Sakit Palang Biru Kutoarjo pada tanggal 9 januari 2014 menunjukan bahwa angka kejadian abortus inkomplit pada bulan januari-desember 2013 masih tinggi yaitu seebesar 57,4\% dari 101 kejadian abortus di Rumah Sakit Palang Biru Kutoarjo. Kejadian abortus inkomplit tersebut $44,8 \%$ oleh usia ibu lebih dari 35 tahun dan 10,3\% usia ibu kurang dari 20 tahun. Sedangkan $44,8 \%$ terjadi pada usia 20 sampai 35 tahun.

Berdasarkan penelitian Andriza (2013) tentang hubungan antara umur dan paritas dengan kejadian abortus inkomplit di RSUD Raden Mattaher tahun 2013 bahwa dari 92 responden paritas resiko tinggi sebanyak 44 orang $(47,8 \%)$ dan paritas rendah 48 orang $(52,2 \%)$. Berdasarkan hasil penelitian, Andriza berpendapat bahwa paritas resiko rendah lebih tinggi dari pada paritas resiko tinggi dan hal ini tidak sejalan dengan teori karena salah satu faktor resiko ibu terjadinya abortus dapat dilihat dari riwayat abortus.
Data dari Rekam Medik RSUD Raden Mattaher jumlah Ibu abortus inkomplit tahun 2016 sebanyak 77 orang, tahun 2017 sebanyak 102 orang dan tahun 2018 sebanyak 19 orang.

Berdasarkan latar belakang diatas maka peneliti tertarik untuk melakukan penelitian tentang "Hubungan Antara Umur dan Paritas Ibu Hamil Dengan Kejadian Abortus Inkomplit Di RSUD Raden Mattaher Jambi Tahun 2018"

\section{METODE PENELITIAN}

Penelitian ini menggunakan desain penelitian kuantitatif dengan pendekatan desain case control yaitu penelitian untuk mempelajari antara faktor-faktor dengan efek dengan cara pendekatan observasi atau pengumpulan data sekaligus pada suatu saat artinya tiap subjek penelitian hanya di observasi sekali saja dan pengukuran dilakukan terhadap status karakter atau variabel subjek pada saat pemeriksaan (Notoatmodjo, 2010).

Populasi adalah keseluruhan objek penelitian atau objek yang diteliti (Notoatmodjo, 2010). Populasi dalam penelitian ini adalah semua ibu hamil yang mengalami abortus sebanyak 75 responden di RSUD Raden Mattaher Jambi Tahun 2018.

Teknik pengambilan sampel yang digunakan pada penelitian ini adalah teknik Total Populasi yaitu mengambil seluruh populasi yang tersedia atau ada (Notoatmodjo, 2010). Sampel pada penelitian ini adalah semua ibu hamil yang mengalami abortus di RSUD Raden Mattaher Jambi Tahun 2018 berjumlah 75 responden.

HASIL PENELITIAN

Analisa Univariat

Tabel 1 Distribusi Frekuensi Kejadian Abortus Inkomplit Pada Ibu Hamil di RSUD Raden Mattaher Jambi Tahun 2018

\begin{tabular}{cccc}
\hline No & $\begin{array}{c}\text { Kejadian } \\
\text { Abortus } \\
\text { Inkomplit }\end{array}$ & n & Presentasi (\%) \\
\hline 1 & Ya & 23 & 30.7 \\
\hline 2 & Tidak & 52 & 69.3 \\
\hline & Total & 75 & 100 \\
\hline
\end{tabular}


Dari Tabel 1 diatas, dapat diketahui bahwa ibu hamil yang mengalami abortus inkomplit yaitu sebanyak 23 responden $(30,7 \%)$ dan tidak mengalami abortus inkomplit sebanyak 52 responden $(69,3 \%)$.

\section{Umur}

Tabel 2 Distribusi Frekuensi Umur Pada Ibu Hamil di RSUD Raden Mattaher Jambi Tahun 2018

\begin{tabular}{cccc}
\hline No & Umur & n & Presentasi (\%) \\
\hline 1 & Resiko Tinggi & 27 & 36,7 \\
\hline 2 & Resiko rendah & 48 & 63,3 \\
\hline & Total & 75 & 100
\end{tabular}

Dari tabel 2 diatas, dapat diketahui bahwa dari 75 responden didapatkan responden yang umur resiko tinggi sebanyak 27 responden $(36,7$ $\%)$ dan umur resiko rendah sebanyak 48 responden $(63,3 \%)$.

2. Paritas

Tabel 3 Distribusi Frekuensi Paritas Pada Ibu Hamil di RSUD Raden Mattaher Jambi Tahun 2018

\begin{tabular}{cccc}
\hline No & Umur & n & $\begin{array}{c}\text { Presentasi } \\
(\mathbf{\%})\end{array}$ \\
\hline 1 & Resiko Tinggi & 21 & $28,0 \%$ \\
\hline 2 & Resiko rendah & 54 & $72,0 \%$ \\
\hline & Total & 75 & 100 \\
\hline
\end{tabular}

Dari tabel 3 diatas, dapat diketahui bahwa dari 75 responden didapatkan responden yang paritas resiko tinggi sebanyak 21 responden $(28,0 \%)$ dan paritas resiko rendah sebanyak 54 responden $(72,0 \%)$.

\section{Analisa Bivariat}

Hubungan antara umur dengan kejadian abortus inkomplit pada ibu hamil

Tabel 4 Distribusi umur berdasarkan kejadian Abortus Inkomplit Pada Ibu Hamil di RSUD Raden Mattaher Jambi Tahun 2018

\begin{tabular}{|c|c|c|c|c|c|c|c|c|}
\hline \multirow{3}{*}{$\begin{array}{l}\mathbf{N} \\
\mathbf{o}\end{array}$} & \multirow[t]{3}{*}{ Umur } & \multicolumn{4}{|c|}{ Abortus Inkomplit } & \multirow{2}{*}{\multicolumn{2}{|c|}{ Jumlah }} & \multirow{3}{*}{$\begin{array}{c}p \\
\text { value }\end{array}$} \\
\hline & & \multicolumn{2}{|c|}{ Ya } & \multicolumn{2}{|c|}{ Tidak } & & & \\
\hline & & $\mathbf{n}$ & $\%$ & $\mathbf{n}$ & $\%$ & $\mathbf{N}$ & $\%$ & \\
\hline 1. & $\begin{array}{l}\text { Resiko } \\
\text { Tinggi }\end{array}$ & 15 & 55,6 & 12 & 44,4 & 27 & 100 & 0,001 \\
\hline \multirow[t]{2}{*}{2.} & $\begin{array}{l}\text { Resiko } \\
\text { Rendah }\end{array}$ & 8 & 16,7 & 40 & 83,3 & 48 & 100 & \\
\hline & & 23 & 30,7 & 52 & 69,3 & 75 & 100 & \\
\hline
\end{tabular}

Dari hasil tabel diatas bahwa 27 responden yang memiliki resiko tinggi yang mengalami abortus inkomplit sebanyak 15 orang $(55,6 \%)$ dan yang tidak mengalami abortus inkomplit sebanyak 12 orang $(44,4 \%)$. Sedangkan dari 48 responden didapatkan ibu yang memiliki umur resiko rendah yang mengalami abortus inkomplit sebanyak 8 orang $(16,7 \%)$ dan tidak mengalami abortus inkomplit sebanyak 40 orang $(83,3 \%)$. Dari hasil uji statistik Chi-Square didapatkan nilai $p$ value $=$ 0,001 berati $p$ value < $\alpha$ jadi dapat disimpulkan bahwa hipotesis ada hubungan yang bermakna antara umur dengan kejadian abortus inkomplit pada ibu hamil.

Hubungan antara Paritas dengan Kejadian Abortus Inkomplit Pada Ibu Hamil

Tabel 5 Distribusi Paritas berdasarkan Kejadian Abortus Inkomplit Pada Ibu Hamil di RSUD Raden Mattaher Jambi Tahun 2018

\begin{tabular}{|c|c|c|c|c|c|c|c|c|}
\hline \multirow{3}{*}{$\begin{array}{l}\mathbf{N} \\
\mathbf{o}\end{array}$} & \multirow{3}{*}{ Paritas } & \multicolumn{4}{|c|}{ Abortus Inkomplit } & \multirow{2}{*}{\multicolumn{2}{|c|}{ Jumlah }} & \multirow{3}{*}{$\begin{array}{c}p \\
\text { value }\end{array}$} \\
\hline & & \multicolumn{2}{|c|}{ Ya } & \multicolumn{2}{|c|}{ Tidak } & & & \\
\hline & & $\mathbf{n}$ & $\%$ & $\mathbf{n}$ & $\%$ & $\mathbf{n}$ & $\%$ & \\
\hline 1. & $\begin{array}{l}\text { Resiko } \\
\text { Tinggi }\end{array}$ & 14 & 66,7 & 7 & 33,3 & 21 & 100 & 0,000 \\
\hline \multirow[t]{2}{*}{2.} & $\begin{array}{l}\text { Resiko } \\
\text { Rendah }\end{array}$ & 9 & 16,7 & 45 & 83,3 & 54 & 100 & \\
\hline & & 23 & 30,7 & 52 & 69,3 & 75 & 100 & \\
\hline
\end{tabular}

Dari hasil tabel diatas bahwa 21 responden yang memiliki paritas resiko tinggi yang mengalami abortus inkomplit sebanyak 14 orang $(66,7 \%)$ dan yang tidak mengalami abortus inkomplit sebanyak 7 orang $(33,3 \%)$. Sedangkan dari 54 responden didapatkan ibu yang memiliki paritas resiko rendah yang mengalami abortus inkomplit sebanyak 9 orang $(16,7 \%)$ dan tidak mengalami abortus inkomplit sebanyak 45 orang $(83,3 \%)$. Dari hasil uji statistik Chi-Square didapatkan nilai $p$ value $=$ 0,000 berati $p$ value $<\alpha$ jadi dapat disimpulkan bahwa hipotesis menyatakan ada hubungan yang bermakna antara paritas dengan kejadian abortus inkomplit pada ibu hamil.

\section{PEMBAHASAN}

Pembahasan hasil penelitian ini berdasarkan analisa data dan temuan di lapangan 
selanjutnya untuk memberikan konstribusi untuk mengetahui adanya hubungan antara umur dan paritas dengan kejadian abortus inkomplit di RSUD Raden Mattaher Jambi Tahun 2018.

\section{Kejadian Abortus Inkomplit}

Dalam penelitian ini variabel dependen (kejadian abortus inkomplit) dikategorikan menjadi dua yaitu ya dan tidak. Ya (jika ibu mengalami abortus inkomplit) dan tidak (jika ibu tidak mengalami abortus inkomplit).

Berdasarkan hasil penelitian ini menunjukkan bahwa dari 75 ibu hamil yang mengalami abortus inkomplit sebanyak 23 orang $(30,7 \%)$ dan tidak mengalami abortus inkomplit sebanyak 52 orang $(69,3 \%)$.

Hasil Penelitian ini sejalan dengan penelitian yang dilakukan oleh Silmi (2013) di Rumah Sakit Prikasih Jakarta Selatan didapatkan dari 317 responden terdapat 117 orang $(36,9 \%)$ yang mengalami abortus inkomplit. Hal ini dikarenakan banyak faktor yang mempengaruhinya yaitu umur ibu yang terlalu muda untuk mengalami kehamilan $(<$ 20 tahun) dapat menyebabkan perdarahan karena endometrium masih belum sempurna, sedangkan umur resiko tinggi ( $<35$ tahun) dapat menyebabkan perdarahan karena pertumbuhan endometrium kurang subur (Prawirohardjo, 2010).

\section{Umur}

Dalam Penelitian ini variabel independen (umur) dikategorikan menjadi dua yaitu resiko tinggi dan resiko rendah. Resiko tinggi (jika usia $<20$ tahun atau $>35$ tahun) dan resiko rendah (jika usia antara 20 -35 tahun).

Berdasarkan hasil penelitian ini menunjukkan bahwa dari 75 ibu hamil didapatkan ibu hamil yang umur resiko tinggi sebanyak 27 orang $(36,7 \%)$ dan ibu hamil yang umur resiko rendah 48 orang $(63.3 \%)$.

Hasil Penelitian ini tidak sejalan dengan penelitian yang dilakukan oleh Elvira (2013) di RSUD Rokan Hulu didapatkan dari 132 responden yang umur resiko tinggi yang mengalami abortus inkomplit sebanyak 83 responden $(63 \%)$ dan umur resiko rendah sebanyak 49 ibu hamil (37\%). Karena menurut teori Draper (2005) bahwa faktor umur ibu mempunyai pengaruh terhadap kehamilan dan persalinan, ibu yang berumur dibawah 20 tahun atau diatas 35 tahun sangat beresiko untuk mengalami abortus inkomplit. Kehamilan ibu dengan usia dibawah 20 tahun berpengaruh kepada kematangan fisik dan mental dalam menghadapi masa kehamilan.

Berdasarkan penelitian yang dilakukan Deby (2014), tentang gambaran umur dan paritas ibu hamil dengan kejadian abortus di Rumah Sakit Muhammadiyah Palembang, didapatkan hasil umur ibu yang mengalami abortus inkomplit lebih banyak pada umur resiko rendah sebanyak 31 responden $(59,6 \%)$ dan umur resiko tingggi sebanyak 21 responden $(40,4 \%)$.

Studi pendahuluan yang dilakukan oleh peneliti di Rumah Sakit Palang Biru Kutoarjo pada tanggal 9 januari 2014 menunjukan bahwa angka kejadian abortus inkomplit pada bulan januari-desember 2013 masih tinggi yaitu seebesar 57,4\% dari 101 kejadian abortus di Rumah Sakit Palang Biru Kutoarjo. Kejadian abortus inkomplit tersebut $44,8 \%$ oleh usia ibu lebih dari 35 tahun dan $10,3 \%$ usia ibu kurang dari 20 tahun. Sedangkan $44,8 \%$ terjadi pada usia 20 sampai 35 tahun.

Usia hamil yang ideal bagi seorang wanita adalah antara umur 20-35 tahun, karena pada usia tersebut rahim sudah siap menerima kehamilan, mental juga sudah matang dan sudah mampu merawat sendiri bayi dan dirinya.

\section{Paritas}

Dalam penelitian ini variabel independen (paritas) dikategorikan menjadi dua yaitu resiko tinggi dn resiko rendah. Resiko tinggi (jika ibu melahirkan > 3 anak) dan resiko rendah (jika ibu melahirkan 2-3 anak).

Berdasarkan hasil penelitian ini menunjukkan bahwa dari 75 ibu hamil didapatkan ibu hamil yang paritas resiko tinggi sebanyak 21 orang $(28,0 \%)$ dan ibu hamil yang paritas resiko rendah 54 orang $(72,0 \%)$.

Hasil penelitian ini tidak sejalan dengan penelitian yang dilakukan oleh Dede, dkk (2013) di RSUD Dr. H. Moch. Ansari Saleh Banjar Masin didapatkan dari 122 responden yang paritas resiko tinggi yang mengalami abortus inkomplit sebanyak 66 
orang $(54,1 \%)$ dan paritas resiko rendah sebanyak 56 orang $(45,9 \%)$. Karena menurut teori Wiknjosastro, 2010 paritas resiko rendah (2-3) merupakan paritas paling aman ditinjau dari sudut kematian paritas tinggi (lebih dari 5 kali) mempunyai angka kematian maternal lebih tinggi. Lebih tinggi paritas lebih tinggi kematian maternal, resiko pada paritas 1 dapat ditangani dengan asuhan obstetrik lebih baik sedangkan resiko paritas tinggi dapat dikurangi atau dicegah dengan keluarga berencana. Pada multipara uterus sudah terlalu sering dibuahi sehingga keadaan uterus melemah.

Berdasarkan penelitian yang dilakukan oleh Ningsih (2012) di RSUD dr. Zainoel Abidin Banda aceh menyatakan bahwa terdapat hubungan antara paritas dengan kejadian abortus dengan $p$ value 0,007. Dengan demikian ibu yang memiliki paritas tinggi atau ibu yang memiliki paritas tinggi atau multipara beresiko terjadinya abortus. Angka kejadian pada hasil penelitian banyak terdapat abortus pada multipara dan semakin tinggi kejadiannya pada grande multipara. Kejadian abortus pada ibu pada paritas tinggi berkaitan dengan kesehatan ibu karena kurangnya istirahat dan hamil yang terlalu dekat, apalagi bila disertai dengan abortus pada kehamilan sebelumnya.

Berdasarkan penelitian Andriza (2013) tentang hubungan antara umur dan paritas dengan kejadian abortus inkomplit di Rumah Sakit Muhammadiyah Palembang tahun 2013 bahwa dari 92 responden paritas resiko tinggi sebanyak 44 orang $(47,8 \%)$ dan paritas rendah 48 orang $(52,2 \%)$. Berdasarkan hasil penelitian, Andriza berpendapat bahwa paritas resiko rendah lebih tinggi dari pada paritas resiko tinggi dan hal ini tidak sejalan dngan teori karena salah satu faktor resiko ibu terjadinya abortus dapat dilihat dari riwayat abortus.

Berdasarkan penelitian Handayani (2013) tentang hubungan antara umur dan paritas dengan kejadian abortus inkomplit di RSUD Rokan Hulu tahun 2013 menyatakan bahwa ada hubungan paritas dengan kejadian abortus inkomplit $\mathrm{p}$ value 0,000 . Berdasarkan hasil penelitian, Eka berpendapat bahwa ibu yang memiliki paritas tinggi atau multipara beresiko terjadinya abortus.

\section{A. Hubungan antara umur dengan kejadian abortus inkomplit di RSUD Raden Mattaher Jambi Tahun 2018}

Dari hasil analisis didapatkan bahwa dari 27 ibu hamil didapatkan ibu hamil yang umur resiko tinggi dan mengalami abortus inkomplit sebanyak 15 orang $(55,6 \%)$ dan tidak mengalami abortus inkomplit sebanyak 12 orang $(44,4 \%)$. Sedangkan dari $48 \mathrm{ibu}$ hamil didapatkan ibu hamil yang umur resiko rendah dan mengalami abortus inkomplit sebanyak 8 orang $(16,7 \%)$ dan tidak mengalami abortus inkomplit sebanyak 40 orang $(83,3 \%)$.

Dari uji statistik Chi-square didapatkan $p$ value $=0,001(\alpha<0,05)$ yang berati $\mathrm{Ha}$ diterima. Dengan demikian pada penelitian ini disimpulkan bahwa ada hubungan antara umur dengan kejadian abortus inkomplit di RSUD Raden Mattaher Jambi Tahun 2018.

Hasil penelitian ini sesuai dengan hasil penelitian Lukitasari (2010) dilakukan di RSU H.M Ryacudu, dimana pada hasil penelitiannya ada hubungan yang bermakna antara umur dengan kejadian abortusinkomplit $p$ value $=0,001(\alpha<0,05)$

Dari teori Donny (2014), menyatakan bahwa wanita yang hamil pada usia kurang 20 tahun retan mengalami abortus. Hal itu disebabkan karena belum matangnya alat reproduksi untuk hamil sehingga dapat merugikan kesehatan ibu maupun pertumbuhan dan perkembangan janin. Sedangkan abortus yang terjadi pada usia 35 tahun disebabkan karena berkurangnya fungsi alat reproduksi, kelainan kromosom.

Dalam hal ini peneliti berasumsi bahwa umur ibu yang < 20 tahun atau > 35 tahun dapat menyebabkan resiko pada kehamilan. Di umur ibu $<20$ tahun secara biologis belum matang emosinya masih cenderung labil, psikis dan mentalnya belum siap untuk hamil sehingga mudah mengalami keguncangan yang mengakibatkan kurangnya perhatian pada saat hamil dan kurangnya pemenuhan zat-zat kebutuhan pad saat hamil sedangkan ibu yang berumur > 35 tahun berkaitan dngan kemunduran dan penurunan 
daya tahan tubuh sehingga berbagai macam penyakit sering menimpa pada usia 35 tahun. Semakin tinggi umur ibu maka semakin beresiko untuk terjadinya abortus.

B. Hubungan antara paritas dengan kejadian abortus inkomplit di RSUD Raden Mattaher Jambi Tahun 2018

Dari hasil analisis didapatkan bahwa dari 21 ibu hamil didapatkan ibu hamil yang paritas resiko tinggi dan mengalami abortus inkomplit sebanyak 14 orang $(66,7 \%)$ dan tidak mengalami abortus inkomplit sebanyak 7 orang $(33,3 \%)$. Sedangkan dari $54 \mathrm{ibu}$ hamil didapatkan ibu hamil yang paritas resiko rendah dan mengalami abortus inkomplit sebanyak 9 orang $(16,7 \%)$ dan tidak mengalami abortus inkomplit sebanyak 45 orang $(83,3 \%)$.

Dari uji statistik Chi-square didapatkan $p$ value $=0,000(\alpha<0,05)$ yang berati $\mathrm{Ha}$ diterima. Dengan demikian pada penelitian ini disimpulkan bahwa ada hubungan antara umur dengan kejadian abortus inkomplit di RSUD Raden Mattaher Jambi Tahun 2018.

Hasil penelitian ini sesuai dengan hasil penelitian Handayani (2013) di RSUD Rokan Hulu, dimana pada hasil penelitiannya ada hubungan yang bermakna antara paritas dengan kejadian abortus inkomplit dengan $p$ value $=0,000(\alpha<0,05)$.

Dari teori Donny (2014), menyatakan bahwa jumlah paritas yang tinggi juga mempengaruhi angka kejadian abortus. Risiko terjadinya abortus meningkat seiring dengan bertambahnya paritas ibu lebih dari 3 kali mempunyai angka kematian maternal lebih tinggi. Semakin tinggi paritas maka akan semakin beresiko kehamilan dan persalinan, karena pada wanita yang sering hamil ataupun melahirkan akan mengalami kekendoran pada dinding rahim.

Dalam hal ini peneliti berasumsi bahwa ibu yang berparitas 2-3 merupakan paritas paling aman sedangkan ibu yang berparitas lebih dari 3 maka akan beresiko terjadinya kematian maternal lebih tinggi. Maka lebih tinggi paritas lebih tinggi juga kematian maternal, ibu yang berparitas rendah dapat ditangani dengan asuhan kebidanan obstetrik sedangkan ibu yang berparitas tinggi dapat ditangani dengan cara dikurangi atau dicegah dengan keluarga berencana. Semakin tinggi paritas maka semakin beresiko akan mengalami abortus.

\section{KESIMPULAN}

Berdasarkan penelitian yang dilakukan pada 75 sampel ibu hamil di RSUD Raden Mattaher tentang hubungan umur dan paritas dengan kejadian abortus inkomplit pada ibu hamil di RSUD Raden Mattaher Jambi Tahun 2018 didapatkan kesimpulan bahwa hubungan antara umur dengan kejadian abortus inkomplit di RSUD Raden Mattaher Jambi Tahun 2018 dengan $p$ value $=0,001$, Ada hubungan antara paritas dengan kejadian abortus inkomplit di RSUD Raden Mattaher Jambi Tahun 2018 dengan $p$ value $=0,000$

\section{DAFTAR PUSTAKA}

Andriza, 2013. Hubungan Umur Dan Paritas Ibu Hamil Dengan Kejadian Abortus Inkomplit Di Rumah Sakit Muhammadiyah Palembang, 2013. Jurnal Prodi D III Kebidanan STIK Bina Husada, Palembang, 2013. Diakses tanggal 26 September 2018.

Azhari, 2011. Upaya menurunkan angka kesakitan dan angka kematian ibu. Diakses tanggal 26 September 2018. Dari

http:adln.lib.unair.ac.id/files/diskl/536/g dlhub-gdl-s3-2013-yusrizalfe-26755-19daf-a.pdf.

Cunningham, 2012. Obstetri William. Edisi Kedelapan Belas

Deby Meitia Sandy, 2014. Gambaran Umur Dan Paritas Ibu Hamil Dengan Kejadian Abortus Inkomplit Di Rumah Sakit Muhammadiyah Palembang Tahun, 2014. Jurnal Prodi D III Kebidanan STIK Bina Husada, Palembang, 2014. Diakses Tanggal 26 September 2018.

Dede dkk, 2013. Hubungan antara Paritas dengan Kejadian Abortus Inkomplit di RSUD Dr. H. Moch. Ansari Saleh Banjarmasin Tahun 2013. Diakses tanggal 26 September 2018. 
Depkes RI, 2015. Profil Pelayanan Kesehatan Dasar Angka Kematian ibu di Indonesia.

Dinas Kesehatan Kota Jambi, 2015. Profil Dinas Kesehatan Kota Jambi. Diakses Tanggal 13 September 2018.

Donny Pengemanan, 2014. Hubungan Abortus Inkomplit Dengan Faktor Risiko Pada Ibu Hamil Di Rumah Sakit Pindad Bandung 2013-2014, jurnal Fakultas Kedokteran Universitas Kristen Maranatha, 2014.

Eka Fitri Handayani, 2013. Hubungan antra Umur dan Paritas dengan Kejadian Abortus Inkomplit di RSUD Rokan Hulu Tahun 2013. Diakses tanggal 26 September 2018.

Elisabeth Siwi Walyani, 2015. Ilmu Obstetri. Jakarta.

Elvira, 2013. Hubungan Umur dengan kejadian Abortus Inkomplit di RSUD Rokan Hulu tahun 2013. Diakses tanggal 26 September 2018.

Fadlun, 2014. Asuhan Kebidanan Patologis. Salemba Medika, Jakarta.

Feryanto, 2014. Asuhan Kebidanan Patologis. Salemba Medika, Jakarta.

Kementerian Kesehatan Republik Indonesia, 2015. Profil Kesehatan Indonesia. Diakses tanggal 13 September 2018. Dari http://profil. Kesehatan.indonesia.htlm

Manuaba, 2010. Ilmu Kebidanan, Penyakit Kandungan dan Keluarga Berencana Untuk Pendidikan Bidan. Jakarta. EGC

Maryunani Anik, 2013. Asuhan Kegawatdaruratan dalam Kebidanan. Jakarta: Trans Info Media.

Mocthar, 2013. Sinopsis Obstetri. Jakarta. EGC Notoatmodjo, 2012. Metode Penelitian Kesehatan Edisi Revisi. Jakarta Rineka Cipta

Nugroho Taufan, 2014. Asuhan Keperawatan Maternitas, Anak, Bedah, dan Penyakit dalam. Yogyakarta: Nuha Medika. 2011

Nurcahyo, Jalu 2010. Awas Bahaya Kanker Rahim dan Kanker Payudara. Yogyakarta. Diakses Tanggal 26 September 2018.
Pernoll, 2010. Buku Saku Obstetri dan Ginekologi. Jakarta. EGC

Prawirohardjo, 2010. Ilmu Kebidanan Penerbit Yayasan Bina Pustaka Sarwono Prawirohardjo. Jakarta.

Rukiyah, Aii Yeyeh, 2010. Asuhan Kebidanan Patologi Kebidanan Edisi 4. Jakarta.

Silmi, 2013. Hubungan Umur dengan Kejadian Abortus Inomplit di Rumah Sakit Prikasih Jakarta Selatan, 2013. Diakses tanggal 26 September 2018

WHO, 2014. Pelayanan Kesehatan Ibu di Fasilitas Kesehatan dasar dan Rujukan. Kementerian Kesehatan Republik Indonesia, 2015.

Wiknjosastro, 2010. Ilmu Kandungan. Jakarta Yayasan Bina Pustaka Sarwono Prawiroharjo. 